\title{
Coercive isomorphism in higher education: Direct pressures from the state to the Turkish universities
}

\section{Inci Ozturk}

Department of HRM and Organisational Behaviour, University of Southampton, UK

\begin{abstract}
The universities maintain their continuity with the pressure of complying with the policies of the state and global policies. This study addresses the coercive pressure of the higher education policies of the state on the Turkish universities. The elective classes of Occupational Knowledge and Area Training to be taught at the universities may be opened when they are approved by the Higher Education Council (Yuksekogretim Kurulu, YOK) which is an institution having a public legal entity. On the other hand, the ability of the universities to determine the elective class of Liberal Education indicates a rare situation where the universities exercise their autonomy.
\end{abstract}

Keywords: Isomorphism; coercive isomorphism; higher education policy, higher education, university 


\section{Introduction}

The policies of the state and global policies affect higher education as it is also the case in various other sectors, because it is unimaginable for a closed system to maintain its existence for a long time where no external impact exists. The economy, technology, legal regulations and agreements create pressures on the institutions. The institutions are unable to avoid the coercive pressures of the national and global policies. In this study, the direct pressures that the Turkish universities experience are elaborated through the example of the fact that the elective classes to be taught at the universities are subject to the approval of the Higher Education Council which is a supreme institution. In this regard, the titles of coercive isomorphism and coercive isomorphism in the Turkish universities are provided here respectively.

\section{Coercive Isomorphism}

\subsection{Definition}

The coercive isomorphism is a process which originates from both the formal and informal pressures that the organizations put on that particular organization with which it is tied to through the cultural expectations in the society where the organizations operate (DiMaggio \& Powell, 1991). In other words, the regulatory processes include the establishment of the formal rules, monitoring, and approving actions. The individuals accept the validity and existence of institutionalized systems of rule regardless of the fairness, accurateness and appropriateness of the rules (Colbeck, 2002), because the state as the rule maker occupies the ruling position and exercises its power over these institutions (Gounko \& Smale, 2007).

\subsection{Need for Legitimation of Institutions}

Meyer and Rowan (1977) argued that the organizational structures gradually reflect the rules that have been legitimized by the state and institutionalized at the state level as the hegemony of the rationalized states and other large rational organizations increase in the social life. Consequently, the organizations have gradually become more homogeneous in certain areas and get organized in a way to adapt to a higher structure. At the same time, the limits of the organizations are structurally drawn and their outputs are subjected to a control by the limitations created by the technical activities such as the policies and market (DiMaggio \& Powell, 1991). The existence of a common legal environment affects many aspects of the behaviors and structure of an organization. Other legal and technical requirements of the state similarly shape the organizations (for instance, the changes in budget cycles, annual reports, requirements for financial reporting and the like) (DiMaggio \& Powell, 1991). The power owned by the state or a large social system has to eliminate the difficulties that the organizations experience or to meet the needs of the organizations (Pfeffer \& Salancik, 
1978/2003). When an organization is subjected to an external auditing, evaluation or regulation, it has the tendency to react and resort to an isomorphous transformation by defending itself. As the external pressures increase, the organizations seek to eliminate or diffuse those pressures by changing their procedures. The easiest way of this transformation is to adopt the routines and structures that are legitimately defined by the laws or the state institutions (Frumkin \& Galaskiewicz, 2004).

\section{Coercive Isomorphism in the Turkish Universities}

The universities experience pressures directly from the state and indirectly from international organizations. The competition between the universities for obtaining funds from the state budget (Fay \& Zavattaro, 2016) and their obedience to the new legal regulations that the state has issued regarding the higher education sector (Gounko \& Smale, 2007) may be provided as examples of the direct impact of the state on the universities. The impact of the World Bank may be provided as an example for the coercive pressures of the international organizations, because the dependency of the governments on the loans and technical assistance forces them to accept the agreed conditions or free market reforms and regulatory policies based on budget cuts (Gounko \& Smale, 2007). Additionally, the World Bank provides project support for the higher education institutions in matters such as enrolment into higher education, improvement of teaching and research activities and of the quality of education (Cai, 2010). Another example that may be indicated for the coercive pressures of the international organizations is the Bologna Process (Seyfried, Ansmann, \& Pohlenz, 2019).

Turkish universities experience pressures directly from the state. This situation originates from the centralist state structure in Turkey. The central government makes important decisions regarding the political, constitutional/legal matters and financial resources. Those decisions are under the inspection of the representatives of the central government (Bache, 1999). The Higher Education Council through which the central government manifests its power is a constitutional institution which brings all higher education institutions including the foundation universities under the same roof. The Higher Education Council is an institution having autonomy and public legal entity within the framework of the duties and authority given to itself by the 130th and the 131st Articles of the Turkish Constitution of 1982. The organization, duties, authority, responsibilities and the working principles of the institution are stipulated by the Higher Education Law Numbered 2547 (yok.gov.tr). The purpose of the Law Numbered 2547 is to determine the purposes and principles pertaining to higher education and to establish principles regarding the actions, duties, authority, and responsibilities along with the matters related to teaching and instruction, research, publications, teaching faculty, students and other personnel of institutions of higher education. 
Based on the Law Numbered 2547, various regulations have been issued regarding student exchange programs, graduate teaching and education, principles regarding discipline of students at higher education institutions, higher education quality assurance, promotion and appointment for the position of assistant professorships and associate professorships, scientific research projects of higher education institutions, academic incentive payments, and foundation higher education institutions. While the Head of the Higher Education Council executes the terms of some of the regulations (for instance, Student Discipline of Higher Education Institutions), the Council of Ministers executes the terms of other regulations (for instance, Academic Incentive Payment). In Turkey, 129 state universities, 73 foundation universities and 5 foundation vocational school of higher education are responsible for implementation of these legal regulations (istatistik.yok.gov.tr). A particular higher education institution issues regulations and directives to provide its operations. The directives of the universities are primarily based on the Law of Higher Education Numbered 2547 and they are accepted by the Senate of that particular university and later they go into effect. The regulations of the university are published in the Official Gazette after being accepted in the University Senate. The stipulations of the regulations and directives of the universities are executed by the University Rector of that particular university. Out of those directives, the most well-known are the regulations and directives that are prepared regarding the examinations and the teaching and instruction of the compulsory and elective classes. Within the scope of the Bologna Process, elective classes must be included in the university curriculum at least by $25 \%$ (YOK, 2018). According to the legal regulations, the elective classes to be opened in the faculties, and vocational schools of higher education are submitted to the Office of the University Rector to be discussed in the University Senate after being approved in the Board of Directors. An explanation takes place regarding opening elective classes among the answers that the Higher Education Council provides for the frequently asked questions regarding the Implementation of Undergraduate Programs of Teaching that the Council has issued in September of 2018. Accordingly, it has become mandatory for the elective classes of Occupational Knowledge and Area Training to be proposed to and accepted by the Higher Education Council after providing their rationale and class description. There is no need for the approval of the Higher Education Council only for the elective class of Liberal Education (yok.gov.tr). In the interviews conducted with the faculty members of the Faculty of Education of Ahi Evran University, Faculty of Education of Kastamonu University and Faculty of Education of Gazi University, Ozturk Fidan (2018) found out that the university faculties were under the pressure of obeying the policies and standards set by the Higher Education Council in determining the classes taught. In this regard, the opinions of some of the faculty members are as follows:

We have a very fixed program dictated by the Higher Education Council. The program of the education faculties is substantially like that which is close to $80 \%$ of the classes (The interviewee refers to the mandatory classes determined by the Higher Education Council). 
The Council already determines the essence of the elective classes. The council says "you may have a Liberal Education class here" "You may have an Occupational Knowledge class there" otherwise, I may not have any class based on my own opinion by saying "It would be nice to have this class" (The interviewee indicates that he/she is unable to have a class based on his/her wish) (Social Sciences Education, Ahi Evran University)

In the education faculties, a highly central impact is experienced. When we want to make an offer for a new class, it is said "No, you may not do that, this class is a basic class dictated by the Higher Education Council" or when you want to take out a class from the curriculum, it is said "These are the basic classes dictated by the Higher Education Council, they may not be removed". You may not indeed add a class if an instruction is not given by the Higher Education Council to the universities or the Office of the University Rector. We were unable to say "I would like to include and teach this class in the program." The approval of the Higher Education Council is definitely required. We were submitting even our elective classes first for the approval of the Office of the University Rector and the University Senate, and after the approval of the University Senate, we were submitting it again for the approval of the Higher Education Council (Science Education, Kastamonu University).

It is even beyond the university to open a non-elective class at the department. We have freedom within the department regarding the elective classes. However, in other classes, there is a hierarchical structure that goes up to the University Senate. Indeed, there is a hierarchical structure that goes to the Higher Education Council from the University Senate (Physics Education, Gazi University).

The findings regarding the pressure of compliance of the universities for the rules set by the Higher Education Council support the conceptualization in the literature regarding isomorphism. Tthe obedience of the universities to the rules that the Higher Education Council sets in the higher education sector, in other words, the existence of the organizational settings that are structured or limited by the Higher Education Council may mean that a limit has been drawn for the university administrations.

The excessive centralist structure of the Higher Education Council introduced the criticisms regarding that the Higher Education Council needed to be rendered as a coordination council. Criticisms have been made regarding that the centralist structure of the Higher Education Council negatively affected the characteristics of higher education, prevented the competitive capacity of the higher education institutions and failed to respond to the needs of the society. It is argued that the administrative, financial and scientific autonomy of the universities would be strengthened, and the universities would become more transparent, accountable and competitive by rendering the Higher Education Council having a structure that would carry out the long-term planning and coordination functions (DPT, 2000). Thus, it is clear that the failure to transform the Higher Education Council into a coordination council created a 
pressure on the functioning of the higher education institutions. According to Bess and Dee (2008) the control of the external forces such as economy, market and technology on the organization is provided by the official arrangements of the state. The members of the organization know that they had limited right of choice, however they also follow-up external orders. Thus, under these circumstances, the organization largely obeys the requests of the environment. In this case, it is understood that the market forces and the political and social pressures create high deterministic settings. On the other hand, according to Scott (1991) in settings devoid of central authority, the organizational forms may show similarities due to the competitive and mimetic processes. The fact that the higher education institutions create their own educational programs and determine the elective Liberal Education classes to be taught at their faculties by themselves may mean that the universities have partially softened the central authority. In this case, in the higher education sector which is shaped by the market conditions, it may be argued that one of the topics where the higher education institutions would be in competition would be regarding attracting successful students to their own universities. It may be said that the universities which compete with each other would followup each other regarding the innovations that they have come up with, and model each other. Nowadays, innovations, changes and variations take place in the educational programs of the foundation universities for the purpose of attracting more students to the universities.

\section{Conclusion}

The universities are obligated to obey the legal regulations of the state. However, the universities also have the tendency to obey the global policies of the international organizations to benefit from their educational and financial support. The obligation of the universities to obey the legal regulations of the state and the global policies lead to the universities to resemble each other. Nowadays, the universities have the purposes of obtaining funds and increasing their number of students. This purpose leads to competition between universities so that the universities are able to survive. One way of being able to compete is to enrich the educational programs of the universities. Different university committees work on placing elective classes into their educational programs, because the elective classes allow the students to increase their chances of employment in the future and explore their potential by taking different classes from different fields instead of specializing only in one field (Toprak \& Erdogan, 2013). However, the fact that the Higher Education Council, which is a supreme institution which gathers universities under its roof, is the final authority approving/disapproving the elective classes that the university committees plan to open, limits the autonomy of the universities.

Briefly, higher education institutions are unable to avoid the coercive pressures of the national and global policies. The competition between the universities for obtaining funds from the state budget and their obedience to the new legal regulations that the state has issued 
regarding the higher education sector show a direct impact of the Turkish state on the universities.

\section{References}

Bache, I. (1999). The extended gatekeeper: Central government and the implementation of EC regional policy in the UK. Journal of European Public Policy, 6(1), 28-45. https://doi.org/10.1080/135017699343784

Bess, J. L., \& Dee, J. R. (2008). Understanding college and university organization: Theories for effective policy and practice. Volume I: The State of the System. Virginia: Stylus Publishing.

Cai, Y. (2010). Global isomorphism and govarnance reform in Chinese Higher Education. Tertiary Education and Management, 16(3), 229-241. https://doi.org/10.1080/13583883.2010.497391

Colbeck, C. L. (2002). Assessing institutionalization of curricular and pedagogical reforms. Research in Higher Education, 43 (4), 397- 421.

DiMaggio, P. J., \& Powell, W. W. (1991b). The iron cage revisited: Institutional isomorphism and collective rationality in organizational fields. In W. W. Powell, \& DiMaggio, P. J. (Eds.), The new institutionalism in organizational analysis. (p. 63-82). Chicago: The University of Chicago Press.

DPT. (2000). Yuksekogretim ozel ihtisas komisyonu raporu. [Higher education specialization commission report]. Ankara: Devlet Planlama Teskilati. Retrieved from http://www.sbb.gov.tr/wp-content/uploads/2018/11/08_Yuksekogretim.pdf

Fay, D. L., \& Zavattaro, S. M. (2016). Branding and isomorphism: The case of higher education. Public Administration Review, September/October, 805-815. https://doi.org/10.1111/puar.12626

Frumkin, P., \& Galaskiewicz, J. (2004). Institutional isomorphism and public sector organizations. Journal of Public Administration Research and Theory, 14(3), 283-307. https://doi.org/10.1093/jopart/muh028

Gounko, T., \& Smale, W. (2007). Modernization of Russian higher education: Exploring $\begin{array}{llll}\text { paths of influence. } & \text { Compare, 37(4), }\end{array}$ https://doi.org/10.1080/03057920701366358

Meyer, J. W., \& Rowan, B. (1977). Institutionalized organizations: Formal structure as myth and ceremony. American Journal of Sociology, 83(2), 340-363.

Meyer, J. W., \& Rowan, B. (1991). Institutionalized organizations: Formal structure as myth and ceremony. In W. W. Powell, \& P. J. DiMaggio (Eds.), The new institutionalism in organizational analysis. (p. 41-62). Chicago: The University of Chicago Press.

Ogretmenlik Lisans Programlarinin Uygulanmasina İliskin Sikca Sorulan Sorular ve Cevaplar. [Frequently Asked Questions and Answers Regarding the Implementation of Teacher Training Undergraduate Programs]. Retrieved from https://www.yok.gov.tr/Documents/Kurumsal/egitim_ogretim_dairesi/Yeni-OgretmenYetistirme-Lisans-Programlari/SSS.pdf 
Ozturk Fidan, I. (2018). Universitelerde iz birakma ve kurumsallasma. [Imprinting and institutionalization at universities]. Yayımlanmamis doktora tezi. [Unpublished doctoral dissertation]. Ankara Universitesi Egitim Bilimleri Enstitusu, Ankara.

Pfeffer, J., \& Salancik, G. R. (2003). The external control of organizations: A resource dependence perspective. CA, USA: Stanford University Press. (Original work published 1978).

Scott, W. R. (1991). Unpacking institutional arguments. In W. W. Powell, \& P. J. DiMaggio (Eds.), The new institutionalism in organizational analysis. (p. 164-182). Chicago: The University of Chicago Press.

Seyfried, M., Ansmann, M., \& Pohlenz, P. (2019). Institutional isomorphism, entrepreneurship and effectiveness: The adoption and implementation of quality management in teaching and learning in Germany. Tertiary Education and Management, 25, 115-129. http://dx.doi.org/10.1007/s11233-019-09022-3

Toprak, M., \& Erdogan, A. (2013). Lisansustu egitimde Avrupa yaklasimi. [European approach to graduate education]. I. Gulec, O. E. Akgun, \& M. Bayrakci (Ed.), VI. Ulusal Lisansustu Egitim Sempozyumu Bildiriler Kitabi (p. 10-36) [VI. National Graduate Education Symposium Proceedings]. Sakarya, Turkiye: Sakarya Universitesi Egitim Bilimleri Enstitusu $\quad$ Yayinlari. $\quad$ Retrieved from http://www.egitim.sakarya.edu.tr/sites/egitim.sakarya.edu.tr/file/ULES-

Lisansustu_egitim_cilt1.pdf\#page=10

YOK. (2018). Oğretmen Yetistirme Lisans Programlari. [Teacher Training Undergraduate Programs]. Retrieved from https://www.yok.gov.tr/Documents/Kurumsal/egitim_ogretim_dairesi/Yeni-OgretmenYetistirme-Lisans-Programlari/AA_Sunus_\%20Onsoz_Uygulama_Yonergesi.pdf

Yuksekogretim Kurulu Mevzuat. [Higher Education Council Legislation]. Retrieved from https://www.yok.gov.tr/kurumsal/mevzuat

Yuksekogretim Bilgi Yonetim Sistemi. [Higher Education Information Management System]. Retrieved from https://istatistik.yok.gov.tr/ 